\title{
Heat loss and energy retention during growth in congenitally obese and lean rats
}

\author{
By J. D. PULLAR AND A. J. F. WEBSTER \\ Rowett Research Institute, Bucksburn, Aberdeen AB2 ${ }_{9} S B$ \\ (Received 20 August $1973-$ Accepted 26 November 1973)
}

\begin{abstract}
I. Heat losses associated with the utilization of metabolizable energy for synthesis of protein and of fat during growth were studied in Zucker rats selected for normal leanness or congenital obesity.

2. Measurements of energy and nitrogen balance were made on groups of four lean and four fat rats offered food $a d l i b$. and kept at $22^{\circ}$. Balance trials were also conducted on groups of fat or lean rats offered restricted amounts of food at two levels and kept at $22^{\circ}$ or $28^{\circ}$. The medium rations offered to fat and lean rats were the same. The energy and $\mathrm{N}$ contents of fat and lean rats were determined by carcass analysis at $35 \mathrm{~d}$ and at about $90 \mathrm{~d}$ of age.

3. At $a d l i b$. intake, fat rats ate $38 \%$ more than lean rats. Heat losses and $\mathrm{N}$ balance were similar. When fat and lean rats were pair-fed, heat loss and $\mathrm{N}$ retention were lower in fat rats. Absolute values and changes during growth of heat loss $(\mathrm{kJ} /$ rat per $24 \mathrm{~h})$ were closely correlated with values obtained for $\mathrm{N}$ balance.

4. Carcass analysis showed that energy retention in protein was, on average, $75 \%$ in lean rats but only $14 \%$ in fat rats. Estimates of energy retention from slaughter experiments and balance trials agreed well, but marked discrepancies existed between the different estimates of $\mathrm{N}$ retention.

5. The net efficiencies of utilization of metabolizable energy for growth in lean and fat rats were 0.485 and $0.61_{4}$ respectively. The energetic efficiencies of net protein synthesis and net fat synthesis were estimated to be 43 and $65 \%$ respectively.

6. The interactions between appetite, growth and activity in the development of obesity in the Zucker rat are discussed.
\end{abstract}

The efficiency with which a growing animal can synthesize protein and fat depends primarily on the amount that it eats. The greater the intake of metabolizable energy (ME) in excess of maintenance requirement, the greater the gross efficiency of energy retention. The net efficiency with which fixed increments of a particular food can promote energy retention in an animal may be obtained by measuring the increment of energy retained $(\mathrm{kJ})$ per Ioo $\mathrm{kJ}$ consumed in excess of maintenance (Blaxter, I962).

Evaluation of different foodstuffs as sources of net energy, e.g. for ruminants, is usually done by measuring their capacity to promote energy retention, principally as fat, in the mature animal (Agricultural Research Council, $1965 ;$ Nehring, r969). This is necessary to ensure that the maintenance energy requirement of the animal does not differ significantly between successive trials and so can be determined with precision (Blaxter, Clapperton \& Wainman, I966). Such experiments cannot however predict the extent to which the efficiency of utilization of energy in the growing animal is affected by the partition of retained energy between protein and fat. The scheme proposed by the Agricultural Research Council (1965) for determining the energy requirements of ruminants for growth avoids the issue by assuming that the efficiency of utilization of $\mathrm{ME}$ for production is constant throughout growth, although of course the partition of retained energy between fat and protein may change considerably. 
More recently several attempts, based on multiple regression analysis, have been made to partition ME requirement for growth into that required for maintenance, for net protein synthesis and for net fat synthesis in rats (Schiemann, I970; McCracken, 1973), pigs (Kielanowski, 1965; Kielanowski \& Kotarbinska, 1970; Oslage, Gädeken \& Fliegel, 1970; Thorbek, 1970; Verstegen, I971), and lambs (Ørskov \& McDonald, 1970). These experiments are all open to the same criticism. Energy requirement for maintenance is very large in relation to that for growth, and changes in maintenance requirement and in the proportion of energy retained as protein are both determined by the same factor, the state of physiological maturity of the animal. Maintenance and protein synthesis cannot therefore be considered as independent variables. Estimates of the energy costs of net protein and net fat synthesis, obtained from the studies listed above, are inconsistent, which is perhaps inevitable because of the high degree of autocorrelation between the measured variables.

In an attempt to circumvent this impasse, we have done experiments with rats of the Zucker strain, in which obesity appears as a simple autosomal recessive trait (Zucker \& Zucker, 196I). Monozygous recessive individuals ('fatties') are obese when offered food ad lib. or even when restricted to an intake paired to that of their lean siblings (Zucker, 1967; Bray, York \& Swerloff, I973). When food intake is restricted, the growth of lean body mass is slower in 'fatties' than in lean individuals. This indicates that the proportion of energy retained in protein is lower in 'fatties' at all stages of growth. Thus one would expect energy exchanges during growth in lean and congenitally fat rats to differ in a way that was independent of maintenance requirement and the state of physiological maturity.

The practical objectives of this study were twofold: to assess how precisely the efficiency of utilizaton of the ME of a food for fattening can be related to its utilization for growth, and to observe the extent to which changes in the efficiency of utilization of food energy contribute to the aetiology of obesity in the Zucker rat.

\section{EXPERIMENTAL}

\section{Animals and diet}

A breeding colony of Zucker rats has been established at the Rowett Institute from stock purchased from the University of Aston, Birmingham. The breeding colony and growing animals were given the same diet as that given to the animals on experiment. The diet was offered $a d l i b$. to all young rats from weaning at about $2 \mathrm{I} \mathrm{d}$, and 'fatty' rats could usually be identified by their appearance within 7-1o d of weaning. 'Fatties' appeared rounder and smaller than their lean siblings at this time. Weight gain in the Ist week after weaning did not differ markedly between fat and lean rats, and it was impossible to diagnose obesity by analysis of blood lipids at this time.

The rats ate a commercial, pelleted, pasteurized diet (Oxoid, Styles (Beardley) Ltd), having (per kg dry matter) $228 \mathrm{~g}$ crude protein, $44 \mathrm{~g}$ fat, $3 \mathrm{I} \mathrm{g}$ crude fibre and a gross energy value of $18.53 \mathrm{MJ}(4.43 \mathrm{Mcal})$. 


\section{Plan of experiments}

The first experiment involved two groups of four rats, fat ones and lean ones, with two males and two females in each group. Each group of four rats was kept in a single cage at about $22^{\circ}$ and offered food $a d$ lib. All uneaten or spilled food was weighed, and a record was kept of food intake. Three sets of measurements were made of the total energy and nitrogen balance of each group when the animals were between 48 and $84 \mathrm{~d}$ old. Details of the conduct of the balance trials are given below. A preliminary account of this experiment has been published (Pullar \& Webster, 1973).

The second experiment was designed to examine energy and $\mathrm{N}$ retention during growth in fat and lean rats when food intake was controlled. Results of the first experiment had shown that the voluntary intake of both fat and lean rats was generally constant between 40 and $85 \mathrm{~d}$ of age. Accordingly, in the second experiment, the ration offered to each group was kept the same throughout. Infertile female fat rats and male lean rats of about $35 \mathrm{~d}$ of age were allotted to four groups. The fat high-ration $(\mathrm{FH})$ group received $3^{\mathrm{I}} \mathrm{g}$ food/rat per $24 \mathrm{~h}$. The fat, medium-ration (FM) and lean, medium-ration (LM) groups received $25 \mathrm{~g} / \mathrm{rat}$ per $24 \mathrm{~h}$ and the lean, low-ration (LL) group received $19 \mathrm{~g} /$ rat per $24 \mathrm{~h}$. The experiment was replicated at $22^{\circ}$ and $28^{\circ}$. This plan permitted a direct comparison between fat and lean rats on the same intake and was intended to compare energy balances within fat and within lean rats at two levels of intake, the upper level in each case being close to appetite. Each of the eight groups was intended to be of four animals. However, one rat in the $\mathrm{FH}$ group kept at $22^{\circ}$ was wrongly identified at the beginning of the experiment and was discovered subsequently to be lean. Because of a shortage of 'fatties' at the right time, the FM and therefore the LM groups at $28^{\circ}$ contained only three animals.

Four sets of measurements were made of total energy and $\mathrm{N}$ balance in each group, although the results were expressed as mean values for each individual. An accurate record was kept of food intake throughout the experiments. When the rats were about $90 \mathrm{~d}$ old they wcre killed by asphyxiation with $\mathrm{CO}_{2}$, and their bodies analysed for energy and N. Two other groups of four lean and four fat rats were killed at $35 \mathrm{~d}$ of age to determine energy and $\mathrm{N}$ contents of the animals at the start of the growth trials. Details of this are given below.

\section{Balance measurements}

The rats were kept throughout in cages with wire floors. The daily ration of food was given at r r.oo hours. During balance trials, urine and faeces that dropped through the wire floor fell through a funnel and were separated using a spider assembly. Urine was collected into conical flasks containing $5 \mathrm{ml}$ of $2 \mathrm{M}_{-} \mathrm{H}_{2} \mathrm{SO}_{4}$. Spilled food fell among the faeces and was carefully separated at the end of each balance trial. The energy contents of food, spillage and excreta were determined by adiabatic bomb calorimetry. $\mathrm{N}$ contents of food, spillage, urine and faeces were determined by the macro-Kjeldahl procedure. In each balance trial, excreta collections were made over $4 \mathrm{~d}$ and the rats were kept for 3 or $4 \mathrm{~d}$ in a gradient layer calorimeter (Pullar, 1969) 
Table I. Daily energy and nitrogen balances of fat and lean rats offered food ad lib. during three periods between 48 and $84 d$ of age

\begin{tabular}{|c|c|c|c|c|c|c|}
\hline \multirow[b]{2}{*}{ Age (d) } & \multicolumn{3}{|c|}{ Fat rats } & \multicolumn{3}{|c|}{ Lean rats } \\
\hline & $48-56$ & $56-64$ & $70-84$ & $48-56$ & $56-64$ & $70-84$ \\
\hline Body-weight (g) & $26 I$ & 318 & $4 I_{3}$ & 187 & 226 & 296 \\
\hline Gross energy intake (kJ(kcal)) & $582($ I39) & $596(142)$ & $525(125)$ & $405(97)$ & $405(97)$ & $422(101)$ \\
\hline $\begin{array}{l}\text { Metabolizable energy intake } \\
(\mathrm{kJ}(\text { kcal }))^{*}\end{array}$ & $43 I(103)$ & $44 \mathrm{r}(\mathrm{r} 05)$ & $378(96)$ & 3 I $5(75)$ & $308(74)$ & $3^{16(75)}$ \\
\hline Heat loss $(\mathrm{kJ}(\mathrm{kcal})) \dagger$ & $228(54)$ & 25 I $(60)$ & $277(66)$ & $218(52)$ & $234(60)$ & $248(57)$ \\
\hline Energy retention $(\mathrm{kJ}(\mathrm{kcal}))$ & $203(49)$ & $190(45)$ & IOI $(24)$ & $97\left(z_{3}\right)$ & $74(\mathrm{I} 8)$ & $68(16)$ \\
\hline $\mathrm{N}$ intake (mg) & I I 43 & 1170 & 1029 & 797 & 796 & 828 \\
\hline $\mathrm{N}$ retention $(\mathrm{mg}) *$ & $3^{60}$ & 320 & 230 & 393 & 361 & 310 \\
\hline \multicolumn{7}{|l|}{ Digestibility } \\
\hline Energy & 0.77 & 0.77 & 0.75 & 0.79 & 0.78 & 0.77 \\
\hline $\mathbf{N}$ & 0.73 & $0.7 \mathrm{I}$ & 0.69 & 0.76 & 0.78 & 0.75 \\
\hline \multicolumn{7}{|l|}{ Reduction to body-weight (g) } \\
\hline ME intake $(\mathrm{kJ} / \mathrm{g}(\mathrm{kcal} / \mathrm{g}))$ & $I .65(0.39)$ & $I \cdot 39(0.33)$ & $0.92(0.22)$ & I. $68(0.40)$ & $I \cdot 36(0.32)$ & $I .07(0.26)$ \\
\hline Heat loss $(\mathrm{kJ} / \mathrm{g}(\mathrm{kcal} / \mathrm{g}))$ & $0.87(0.21)$ & $0.79(0.19)$ & $0.62(0.15)$ & $I \cdot 16(0.28)$ & $I .03(0.25)$ & $0.84(0.20)$ \\
\hline $\mathrm{N}$ retention $(\mathrm{mg} / \mathrm{g})$ & $\mathrm{I} \cdot 37$ & $I \cdot O I$ & 0.56 & $2 \cdot 10$ & $x \cdot 60$ & 1.05 \\
\hline
\end{tabular}

which gave a continuous record of their sensible and evaporative heat loss over periods of $24 \mathrm{~h}$, which began when food was given at II.oo hours.

\section{Comparative slaughter}

The bodies of the 35 -d-old rats were weighed before and after removal of gut contents; the latter weight is referred to hereafter as washed weight. The four rats in each group were then minced into a single sample and freeze-dried. Analyses for energy and $\mathrm{N}$ were done on the freeze-dried material, and results expressed as $\mathrm{kJ}$, or $\mathrm{mg} \mathrm{N}$, per $\mathrm{g}$ washed weight.

The 90-d-old rats were also weighed before and after removal of the gut contents and then dissected into the following: (I) lean body carcass; (2) pelt and subcutaneous fat; (3) liver; (4) head and tail; (5) abdominal fat; (6) blood and viscera. These were weighed separately, then minced together and freeze-dried. Analyses for energy and $\mathrm{N}$ were done in triplicate for each animal.

\section{RESULTS}

Balance trials, rats fed ad lib.

The results of the first series of experiments are summarized in Table I. The rats did not eat more as they grew bigger; in fact, during the final balance period, food intake in the fat rats was reduced. On average, the fat rats ate $38 \%$ more gross energy than lean rats, although the food consumption of both groups was very similar when expressed as $\mathrm{mg} / \mathrm{g}$ body-weight. Mean digestibility ratios of energy were 0.76 and $0 \cdot 78$, and of $\mathrm{N}$ were $0.7 \mathrm{I}$ and 0.76 , for fat and lean rats respectively. Heat loss $(\mathrm{kJ} / \mathrm{rat}$ 

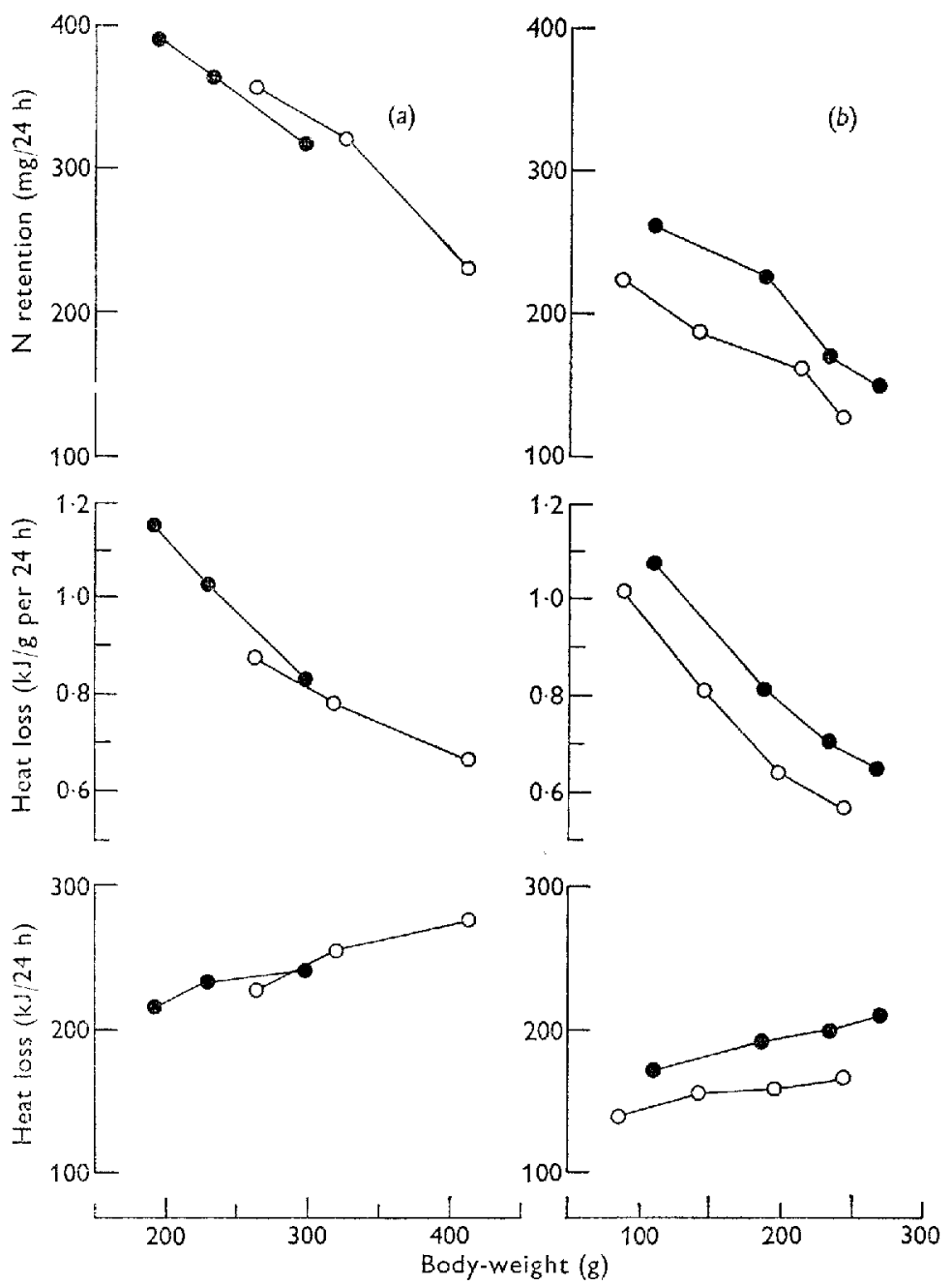

Fig. r. Heat loss and nitrogen retention of fat $(0)$ and lean (6) rats during growth: $(a)$ rats offered food ad lib.; (b) fat and lean rats each eating $25 \mathrm{~g} / 24 \mathrm{~h}$ (medium ration).

per $24 \mathrm{~h}$ ) increased slightly in both groups as they grew older, and energy retention declined. $\mathrm{N}$ retention $(\mathrm{mg} / 24 \mathrm{~h}$ ) declined in both groups as they grew older, and in each period, the rate of $N$ retention was less in the fat than in the lean rats.

Fig. $\mathrm{r} a$ shows that when values for heat loss and $\mathrm{N}$ retention were plotted against body-weight, both fat and lean rats followed a very similar pattern. The lines joining values for heat loss for fat and lean rats are almost identical although the points for the heavier fat rats are displaced further to the right. At any body-weight, therefore, heat loss from fat and lean rats was about the same, although ME intake and thus energy retention were much greater in the 'fatties'. The lines joining values for $\mathrm{N}$ retention $(\mathrm{mg} / 24 \mathrm{~h})$ during growth were also very similar, although $\mathrm{N}$ retention was slightly lower in 'fatties' consuming food ad lib. at all body-weights. The decline in $\mathrm{N}$ retention paralleled the decline in heat loss $(\mathrm{kJ} / \mathrm{g}$ per $24 \mathrm{~h})$. Statistical treatment of these 
(

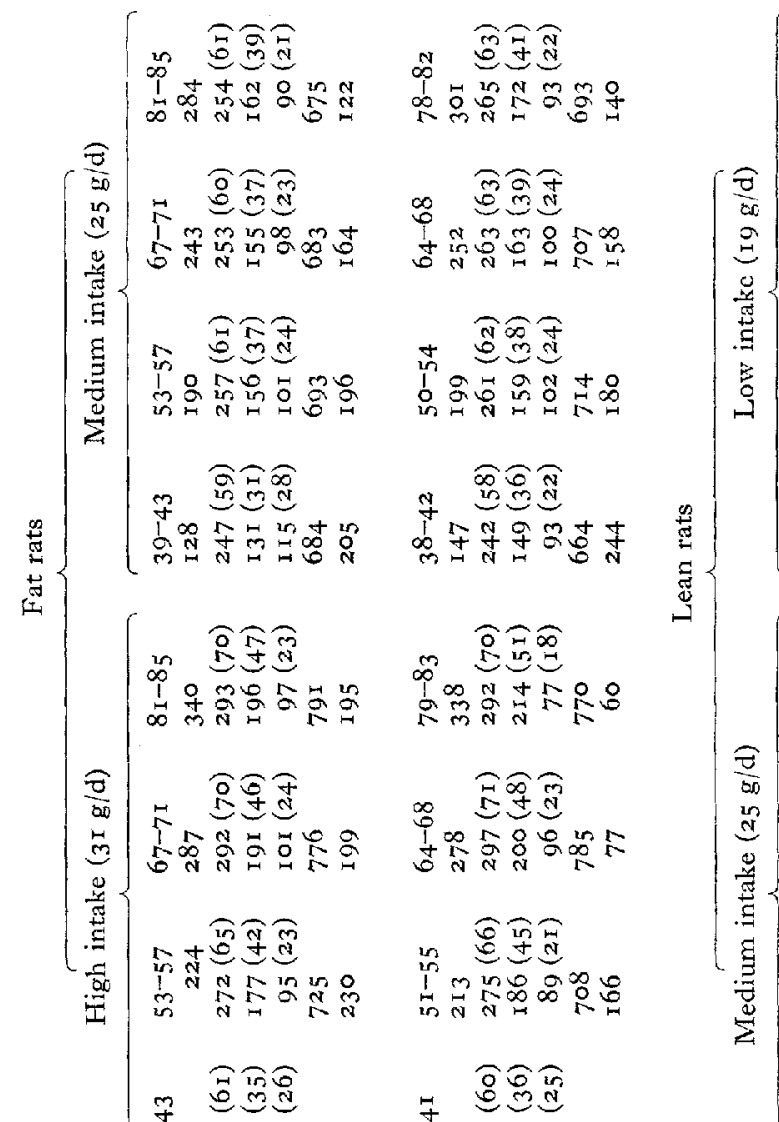

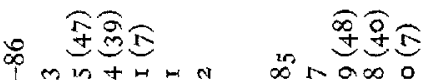

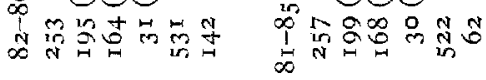

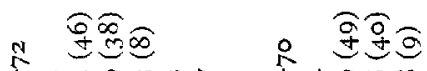

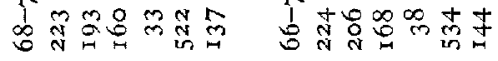

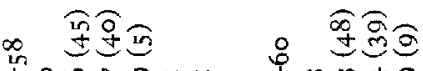

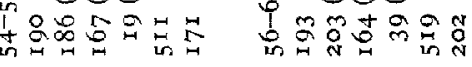

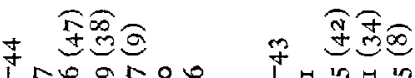

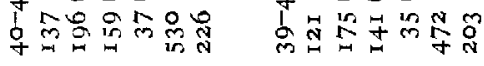

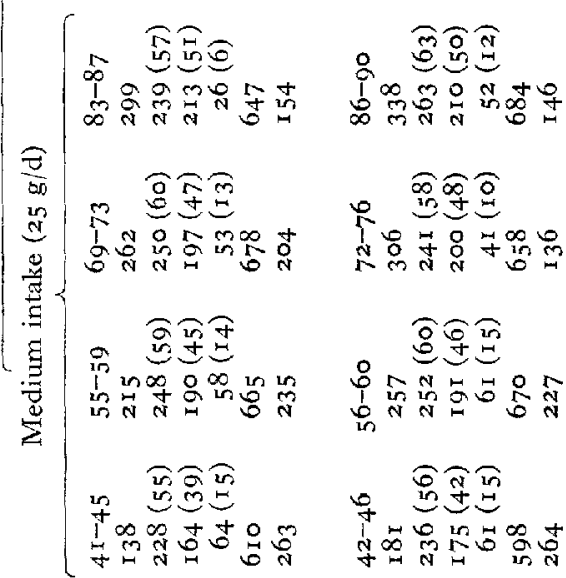

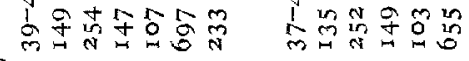

3
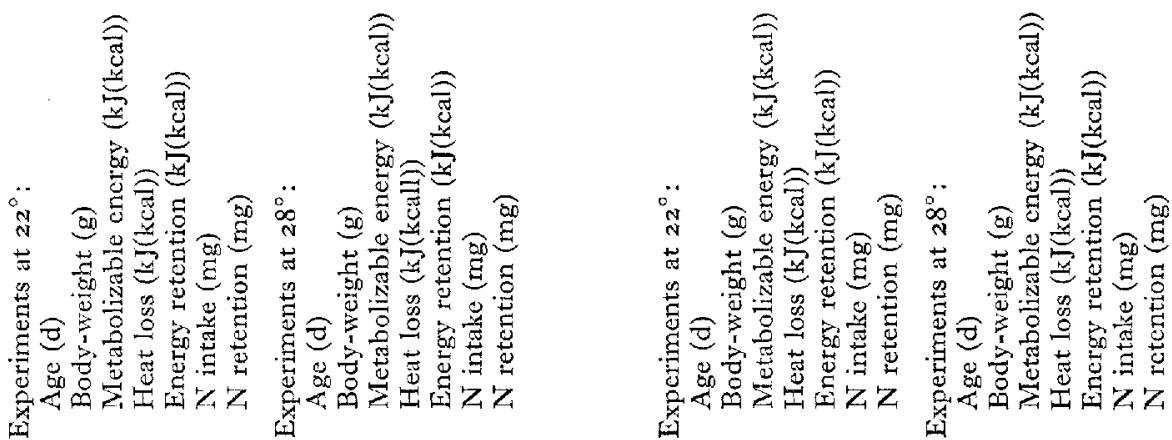


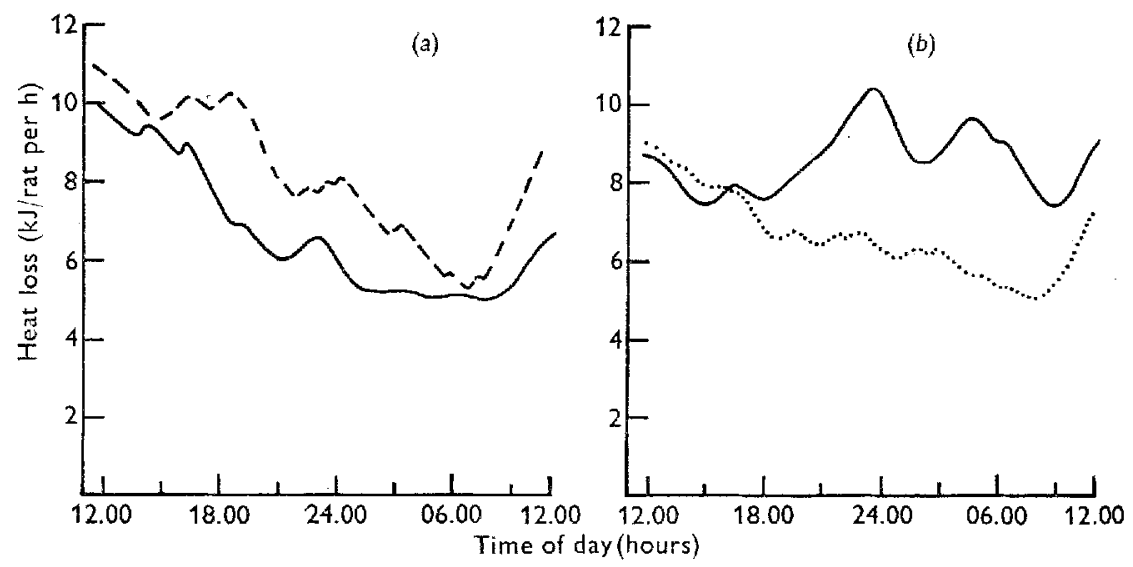

Fig. 2. Pattern of heat losses from fat and lean rats during $24 \mathrm{~h}$. (a) Fat rats: - - , high ration $(\mathrm{FH})$; --, medium ration $(\mathrm{FN})$. (b) Lean rats:- - medium ration (LM); ... low ration (LL).

results is considered below in conjunction with the results of the second series of experiments.

\section{Balance trials, restricted intake}

Energy and $\mathrm{N}$ balances of fat and lean rats kept at $22^{\circ}$ and at $28^{\circ}$ and offered restricted amounts of food are summarized in Table 2. Food intake is expressed in this table only as ME and as total $\mathrm{N}$. There were no statistically significant differences in ability to metabolize the energy of the diet due to level of intake, type of rat or environmental temperature. On average, $72 \cdot 5( \pm 0.87) \%$ of the energy of the diet was metabolized. The experimental plan was such that there should have been a difference of about $30 \%$ in intake of ME between the FH and FM groups and between the LM and LL groups. The actual differences in MF intake were $28 \%$ between the two groups of lean rats but only $9 \%$ between the two groups of fat rats. Only during the first balance trial at each temperature did rats in the FH and LM groups actually refuse any food that was offered. The lack of difference between the intake of the two groups of fat rats was a result of their eating behaviour. Lean rats usually took one pellet at a time from the food rack and ate it before returning for another. When food was offered to the 'fatties', they habitually pulled most of the pellets out of the rack and hoarded them on the floor of the cage before beginning a prolonged period of uninterrupted eating. As a result, the 'fatties' lost more food through the floor of the cage than did the lean rats, and the more food they were given, the more they spilled.

'The 'fatties' finished their daily ration of food more quickly than the lean rats. This difference between fat and lean rats is reflected in their pattern of heat loss during periods of $24 \mathrm{~h}$. Examples of this are shown in Fig. 2. FM rats had usually finished their food by 19.00 hours, and the FH group usually had a little food left when observed at 23.00 hours. Heat losses from fat rats were at their lowest from midnight until about 09.00 hours, when the rats became very active, probably in anticipation of the next meal. The pattern of heat loss in the LL rats, which also usually had eaten all their food by midnight, was similar. The LM rats were the only 


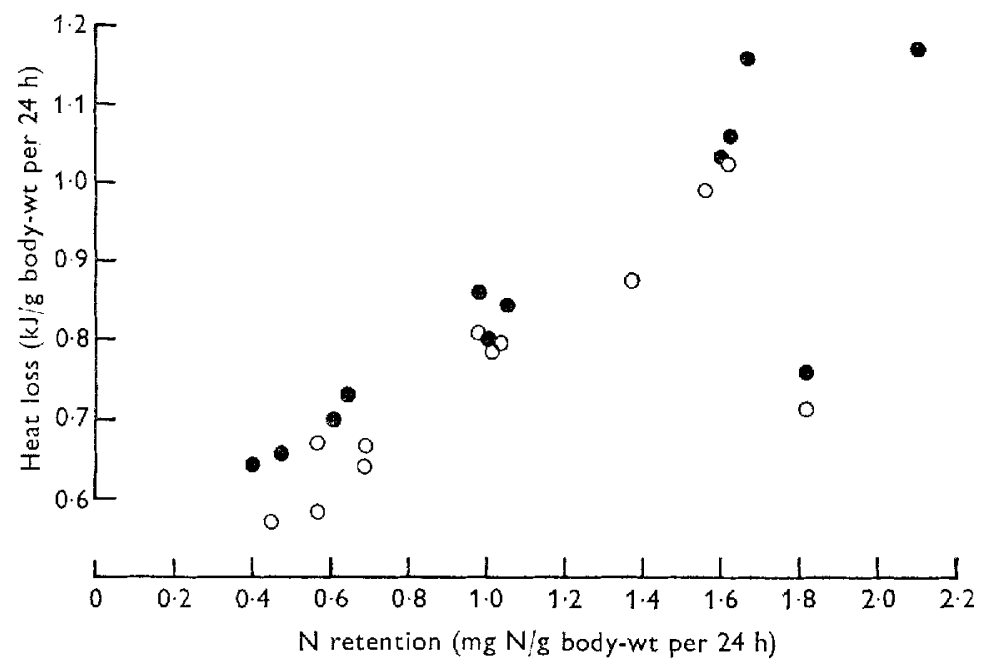

Fig. 3. Relationship between heat loss (kJ/g body-wt per $24 \mathrm{~h}$ ) and nitrogen retention ( $\mathrm{mg} \mathrm{N} / \mathrm{g}$ body-wt per $24 \mathrm{~h}$ ) in fat $(\mathrm{O})$ and lean (O) rats.

group that did not eat most of their daily ration in the first few hours. Like the rats offered food ad lib., they ate most of their ration after 19.00 hours and the pattern of their heat losses reflects this. According to the definition of Fábry (1967), the LM groups and the rats offered food ad lib. were nibblers. All the other groups on restricted food intake were meal-eaters. The two continuous lines in Fig. 2 illustrate heat loss in fat and lean rats at approximately the same weight and the same food intake. Total $24 \mathrm{~h}$ heat loss was clearly greater in the lean animals.

Table 2 shows that heat loss $(\mathrm{kJ} /$ rat per $24 \mathrm{~h})$ in all groups increased during the four periods of the experiment. Analysis of variance of the results showed this increase to be highly significant $(P<0.001)$. Most of the increase, however, was between periods $I$ and 2 . Thereafter, when ME intake was constant, the increase in heat loss ( $\mathrm{kJ} /$ rat per $24 \mathrm{~h}$ ) was quite small.

There was no statistically significant effect of temperature on heat loss. Mean heat losses of all rats at $22^{\circ}$ and $28^{\circ}$ were 170 and $I 75 \mathrm{~kJ} /$ rat per $24 \mathrm{~h} /(40.6$ and $41.8 \mathrm{kcal} / \mathrm{rat}$ per $24 \mathrm{~h}$ ). One may conclude from this that all trials were conducted at air temperatures that were thermoneutral for all groups of rats, so that differences in heat loss between fat and lean rats cannot be attributed to differences in their response to the thermal environment. In subsequent analyses, therefore, trials at $22^{\circ}$ and $28^{\circ}$ have been considered as replicates of the same experiment.

There was a small but statistically significant $(P<0.05)$ decline in energy retention between the first and fourth trials. Mean energy retentions in the FH and FM groups were $96( \pm 3.3)$ and $99( \pm 2.8) \mathrm{kJ} /$ rat per $24 \mathrm{~h}(22.9$ and $23.7 \mathrm{kcal})$ respectively. The difference $(3 \mathrm{~kJ}, 0.8 \mathrm{kcal})$ between these values was not significant. Mean energy retentions in the LM and LL groups were $52( \pm 4.5)$ and $33( \pm 2.4) \mathrm{kJ} /$ rat per $24 \mathrm{~h}$ $(12.4$ and $7.9 \mathrm{kcal})$ respectively, a difference of $19 \mathrm{~kJ}(4.5 \mathrm{kcal})$ which was significant $(P<0.0 \mathrm{I})$.

Mean intakes of metabolizable energy in the FM and LM groups were $255( \pm 2 \cdot 8)$ 
and $245( \pm 3.9) \mathrm{kJ} / 24 \mathrm{~h}(60.9$ and $58.6 \mathrm{kcal})$. This difference (Io $\mathrm{kJ}, 2.3 \mathrm{kcal})$ was significant $(P<0.05)$. Mean energy retention was $99( \pm 2.7) \mathrm{kJ} / 24 \mathrm{~h}(23.7 \mathrm{kcal})$ in the FIM group and $52( \pm 4.5) \mathrm{kJ} / 24 \mathrm{~h}(12.4 \mathrm{kcal})$ in the LM group, a difference $(47 \mathrm{~kJ}$, Ir.3 kcal) which was highly significant $(P<0.00 \mathrm{I})$. Thus, when fat and lean rats consumed very similar amounts of food during growth, 'fattics' retained energy, on average, at a rate almost twice that of the lean rats.

$\mathrm{N}$-balance measurements presented more technical problems than those involved in the measurement of energy balance. These problems were due mainly to cvaporation of urine that came into contact with spilled food. For this reason $\mathrm{N}$-balance measurements were least successful with rats which were kept at the higher temperature and which spilled the most food (FH at $28^{\circ}$ ). The other trials show that the rate of $\mathrm{N}$ retention at approximately constant $\mathrm{N}$ intake declined with age in all groups $(P<$ 0.001 ). Comparisons between periods do not however provide the best description of changes associated with growth. On average, the lean rats were about $4 \mathrm{~d}$ older than the 'fatties' at the time of each balance trial. 'The stage of physiological maturity of a growing animal is, however, better described in terms of body-weight than in terms of days of age. Fig. $\mathrm{x} b$ illustrates changes in heat loss and in $\mathrm{N}$ retention during growth in pair-fed rats (FM and LM) as a function of body-weight. $\mathrm{N}$ retention declined with increasing body-weight in both groups, but at any body-weight $\mathrm{N}$ retention was greater in the lean rats. Both the decline in heat loss $(\mathrm{kJ} / \mathrm{g}$ per $24 \mathrm{~h})$ during growth in FM and LM rats and the absolute differences between fat and lean rats in heat loss paralleled the decline and the absolute differences in $\mathrm{N}$ retention. Heat loss $(\mathrm{kJ} / \mathrm{g}$ per $24 \mathrm{~h}$ ) at any stage of growth appeared to be closely related to the rate of $\mathrm{N}$ retention. This point is illustrated more clearly in Fig. 3, which includes all results given in Tables $\mathrm{I}$ and 2 .

\section{Carcass analysis}

Anatomical differences in carcass composition between fat and lean rats killed at about $90 \mathrm{~d}$ of age are shown in Table 3 . Standard errors for these measurements were small, and were reduced when mean values for all fat and all lean rats were pooled. Direct comparisons between actual weights of different parts of the body in fat and lean rats are not warranted because the rats were killed at different ages and different weights. However, when the weights of the various parts are expressed as a percentage of washed weight it becomes clear that level of food intake had no effect on the relative proportions of the different dissected areas in fat or in lean rats, but that the difference between fat and lean rats was striking; for example, in the lean rats the carcass was $5^{2} \%$ of washed weight, but in the fat rats only $35 \%$.

Energy and $N$ contents of the bodies of fat and lean rats killed at $35 \mathrm{~d}$ and at about $90 \mathrm{~d}$ of age are shown in Table 4 . There was no significant difference between total carcass energies in FH and FM rats. The energy content of the FM groups was more than twice that of the LM groups. This difference was highly significant $(P<0.00 \mathrm{I})$ as was the difference between LM and LL rats.

FH and FM rats contained 8.0 and $6.8 \mathrm{~g} \mathrm{~N}$ respectively. These values did not differ significantly. The $\mathrm{N}$ content of the LM groups was $12.8 \mathrm{~g}$, almost twice that of the FM groups. There was a significant difference in body $\mathrm{N}$ between LM and LL 


\section{Table 3. Composition of carcasses of fat and lean rats killed at about go $d$ of age}

(Mean values with their standard errors for rats kept at $22^{\circ}$ and $28^{\circ}$ )

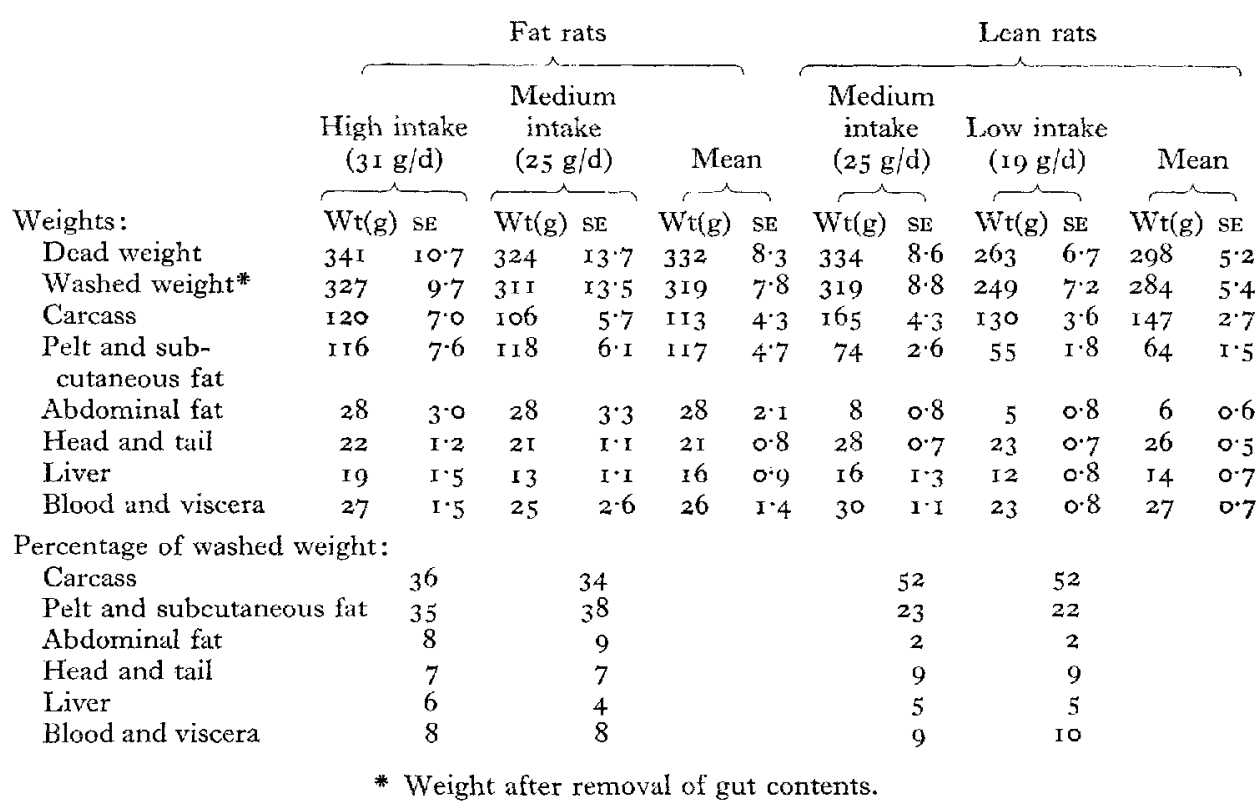

rats $(P<0.01)$, but both groups contained significantly more $\mathrm{N}$ than the FM rats $(P<0.001)$. The difference between fat and lean rats in the partition of retained energy between fat and protein was such that at about $90 \mathrm{~d}$ of age, about $10 \%$ of body-weight, washed free of gut contents, was fat in the lean animals and about $45 \%$ in the obese animals. The proportions of total energy that were retained as protein between 35 and about $90 \mathrm{~d}$ were $8 \mathrm{r} \%$ and $69 \%$ for LL and LM rats respectively and $13 \%$ and $15 \%$ for $\mathrm{FM}$ and $\mathrm{FH}$ rats respectively. The relatively lower proportion of energy retained as protein in the lean rats on the larger ration was as expected, but the relatively higher proportion of energy retained as protein in the fat rats on the larger ration was unforeseen. It indicates that when the food intake of 'fatties' is markedly restricted, the requirement of energy for lipid synthesis has a severely inhibitory effect on the growth of lean body mass.

Table 5 compares measurements made of energy and $N$ retention obtained from carcass analysis with estimates based on the balance trials. Considering the extent of the extrapolation involved in the calculations based on balance results, the agreement between the two approaches to the estimation of energy retention was very close, the balance trials giving a mean value $4.5 \%$ higher than carcass analysis.

The discrepancy between the two methods of measuring $\mathrm{N}$ retention was much greater, especially in the fat rats. $\mathrm{N}$ retention was apparently over-estimated from balance trials with the lean rats by about $44 \mathrm{mg} / 24 \mathrm{~h}$. Similar discrepancies have been observed in many previous trials reviewed by Duncan (1966). In the fat rats the dis- 
Vol. 3I

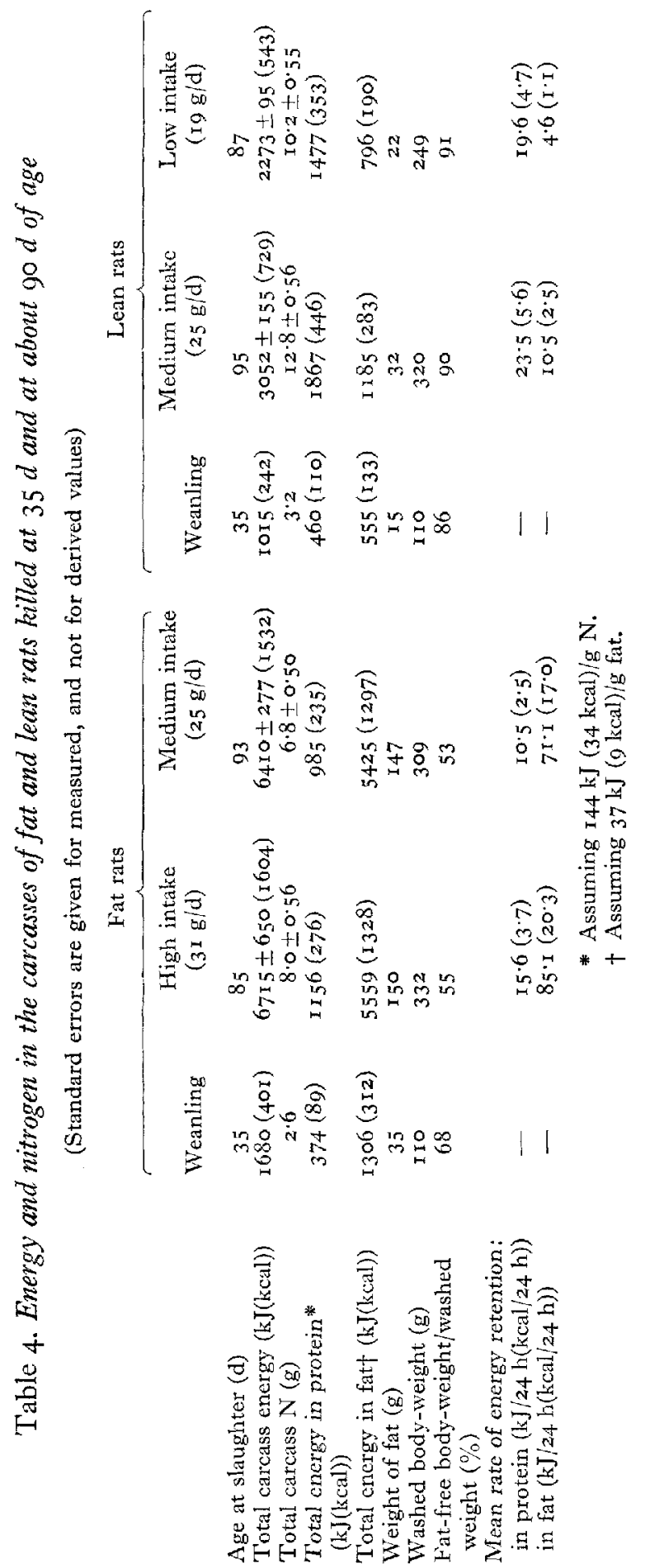


Table 5. Estimation of total energy and nitrogen retention of rats during grozth from 35 to $90 d$ of age, based on carcass analysis and on balance trials

\begin{tabular}{|c|c|c|c|c|}
\hline \multirow[b]{2}{*}{ Group } & \multicolumn{2}{|c|}{ Energy retention $(\mathrm{kJ} / \mathrm{rat}(\mathrm{kcal} / \mathrm{rat}))$} & \multicolumn{2}{|c|}{$N$ retention ( $g /$ rat) } \\
\hline & Slaughter & Balance & Slaughter & Balance \\
\hline Fat, high ration (FH) & $5203(1244)$ & $4747(x+35)$ & $5 * 4$ & $I I \cdot 2$ \\
\hline Fat, medium ration (FM) & $4914(\mathrm{x} \times 74)$ & $5274(1261)$ & $4 \cdot 2$ & $9 \cdot 6$ \\
\hline Lcan, medium ration (LM) & $1898(453)$ & $2507(599)$ & $9 \cdot 6$ & $12 \cdot 8$ \\
\hline Lean, low ration (LL) & $1341(320)$ & $\times 432(342)$ & $7 \cdot 0$ & $8 \cdot 8$ \\
\hline
\end{tabular}

crepancy was $104 \mathrm{mg} / 24 \mathrm{~h}$. Clearly, in these experiments the difference in $\mathrm{N}$ accretion between fat and lean rats was much larger than would be inferred from the $\mathrm{N}$-balance results.

\section{DISCUSSION}

Quantification of the energy requirements for growth

Growth has been defined simply as 'the net balance of mass produced and retained over mass destroyed or otherwise lost' (Weiss \& Kavanau, 1957). In considering the energy requirements for growth, it has been customary to think in the same simple terms, i.e. "the net balance of metabolizable energy retained over that dissipated as heat'. This is the basis of most systems for evaluating the net energy value of foods for growing livestock (Agricultural Research Council, 1965; Nehring, 1969).

In order to predict energy retention at a given rate of intake of metabolizable energy, it is necessary to be able to describe the factors that contribute to heat loss. The present experiments do not provide the values that would enable heat loss during growth to be related to a specific exponent of body-weight. There is considerable evidence from other experiments that so-called metabolic body size $\left(W^{0 \cdot 75}\right)$, which compares fasting metabolism in adults of different species, is not the best exponent by which to relate heat loss to body-weight in the growing individual (Mount, I968). Here therefore the most simple approach to the description of heat loss has bcen adopted, which is to describe it in terms of a basal component $(H=a W+c)$ and the heat increment of feeding $\left(b I_{\mathrm{M}}\right)$ according to the equation

$$
I(\mathrm{~kJ} / 24 \mathrm{~h})=W a+b I_{\mathrm{MI}}+c
$$

where $W=$ body-weight $(\mathrm{g})$ and $I_{M}=\mathrm{ME}$ intake $(\mathrm{kJ} / 24 \mathrm{~h})$. When all the results for fat and lean rats were fitted to this equation using regression analyses, the following results were obtained:

$$
\begin{aligned}
\text { for lean rats } H= & 0.149 W+0.515 I_{\mathrm{M}}+3 \mathrm{I} \quad \mathrm{RSD}= \pm 8.64 \\
& ( \pm 0.036)( \pm 0.050) \\
\text { for fat rats } H= & 0.235 W+0.386 I_{\mathrm{MI}}+\mathrm{I} 2 \quad \mathrm{RSD}= \pm \mathrm{II}^{\circ} \cdot 5 \mathrm{I} \\
& ( \pm 0.04 \mathrm{I})( \pm 0.054)
\end{aligned}
$$

Differences between the regression coefficients 0.149 and 0.235 relating $H$ to $W$, and between the coefficients 0.515 and $0 \cdot 386$ relating $H$ to $I_{\mathrm{M}}$, in lean and fat rats respec- 
tively, both just failed to achieve statistical significance $(0 . \mathrm{I}>P>0.05)$. However, the differences were sufficiently great to suggest that the observed differences between fat and lean rats in heat loss $(\mathrm{kJ} / 24 \mathrm{~h})$ could be attributed both to differences in socalled maintenance energy requirement and in the utilization of metabolizable energy. According to equations $I$ and 2 , the metabolizable energy requirement for maintenance of lean and fat rats at $200 \mathrm{~g}$ (i.e. when $H=I_{\mathrm{HI}}$ ) would be 125 and $96 \mathrm{~kJ} / 24 \mathrm{~h}\left(29^{\circ} 9\right.$ and $22.9 \mathrm{kcal}$ ) respectively, and the efficiency of utilization of ME for growth, 0.485 and $0.6{ }_{1} 4$ for lean and fat rats respectively.

An alternative approach to the evaluation of the energy requirements for growth has been to attempt to account for ME intake in terms of that required for maintenance and that for protein and fat synthesis (Kielanowski \& Kotarbinska, I970; Orskov \& McDonald, 1970; Schiemann, I970; Thorbek, I970):

$$
I_{\mathrm{XI}}=a W^{n}+b_{1} \times \text { protein retention }+b_{2} \times \text { fat retention }+c .
$$

The major criticism to be made of this equation is a statistical one. Since it is ME intake that determines the growth of protein and fat it is not valid to consider it to be the dependent variable. It would be more logical to use heat loss $(I I)$ as the dependent variable.

In a homogeneous group of growing animals, however, either equation becomes difficult to interpret because of the interdependence of the so-called independent variables. For example, as an animal grows, the increase in body-weight is inevitably linked to a decrease in the proportion of energy retained as protein. Moreover, heat losses associated with protein and fat accretion are small compared with those associated with maintenance. Consequently, although the nature of the syntheses involved in growth may have profound effects on the efficiency of energy conversion, these effects are likely to be overwhelmed by uncertainties attached to the estimation of the maintenance component. Thorbek (1970), for example, estimated the efficiency of energy retention as protein in growing pigs to be $43 \%$ using her own formula for estimating maintenance requirement. When she used Brierem's (1939) equally valid formula, the efficiency of energy deposition in protein became $94 \%$.

Zucker rats were used in the present experiments in an attempt to avoid some of these criticisms by selecting animals which differed markedly at all stages of growth in the way in which they partitioned retained energy between protein and fat. Carcass analysis (Table 4 ) shows that this aim was achieved. Lean rats, on average, retained $75 \%$ of their energy as protein, fat rats only $14 \%$. The $\mathrm{N}$-balance trials indicate that the proportion of energy retained in protein declined in both groups of rats as they grew bigger. However, probable errors in the determination of absolute rates of $\mathrm{N}$ retention from balance trials preclude their use in equation 3 to predict the partial efficiencies of energy retention as protein and as fat.

An estimate of the apparent energetic efficiency of protein $\left(E_{\mathrm{p}}\right)$ and of fat accretion $\left(E_{\mathrm{f}}\right)$ can, however, be obtained by expressing the partial efficiencies of utilization of ME in lean rats $\left(k_{\mathrm{I}}\right)$ and in fat rats $\left(k_{\mathrm{f}}\right)$ in terms of the proportions of energy being retained as protein and as fat. Thus, in lean rats,

$$
k_{1}=0.485=0.75 E_{\mathrm{p}}+0.25 E_{\mathrm{f}},
$$


and in fat rats,

$$
k_{\mathrm{f}}=0.6 \mathrm{I} 4=0.14 E_{\mathrm{p}}+0.86 E_{\mathrm{f}} .
$$

On solution of the simultaneous equations (4) and (5): $E_{\mathrm{p}}=0.43 ; \quad E_{\mathrm{r}}=0.65$. The estimate of 0.43 for the efficiency of net protcin synthesis agrees extremely well with that of 0.40 obtained for rats by Schiemann (1970) and those of 0.43 (Thorbek, 1970) and 0.36 (Kielanowski \& Kotarbinska, 1970) in pigs. Previous estimates of the efficiency of net fat synthesis have been $0.7 \mathrm{I}$ in rats (Schiemann, 1970) and 0.77 (Thorbek, 1970) and 0.70 (Kielanowski \& Kotarbinska, 1970) in pigs. A consensus appears to be emerging, from experiments designed in different ways, that the energetic efficiency of net protein synthesis is lower than that of net fat synthesis.

On biochemical grounds, this is to be expected. The energetic efficiency of protein turnover is only about 0.04 (Milligan, 1971). The rate of accretion of structural protein in the muscles of a growing animal is very small indeed in relation to total protein turnover. There are reasonable grounds, however, for supposing that the mean rate of turnover of all body proteins is related to the rate of protein accretion in lean body mass (Arnal, Fauconneau \& Pech, I972; James, 1972; Waterlow, 1969). It is possible, therefore, that the low metabolic rates of the fat rats can be attributed to their low rate of protein turnover relative to the lean animals.

Calorimetric studies with living animals cannot measure the energy cost of protein turnover. What this study does show is that the energy requirements for growth are not independent of the relative rates of accretion of protein and fat, so that any system of food energy evaluation which considers energy requirements for growth as being synonymous with energy requirements for fattening is inherently imprecise and capable of improvement.

\section{Aetiology of obesity in the 'fatty' rat}

The specific nature of the inborn error of metabolism that leads to obesity in the Zucker rat, and the hormonal and biochemical changes that it invokes, have been the subject of many studies (Bray \& York, I97I; York \& Bray, 1972; York, Hershmann, Utiger \& Bray, 1972; Zucker \& Antoniades, I970) which will not be reviewed here. Although the disorder is rare, the outcome, obesity, is all too familiar.

The results of the present experiments provide an extreme example of the irrelevance of measurements of body-weight to the description of obcsity. Rate of gain of body-weight in fat and lean rats pair-fed between 35 and go d of age was about the same (Table 2) although during this time fat and lean rats retained, respectively, $4730 \mathrm{~kJ}$ and $2037 \mathrm{~kJ}$ ( $\mathrm{II} 30$ and $487 \mathrm{kcal}$ ) energy, and synthesized I $16 \mathrm{~g}$ against $24 \mathrm{~g}$ body fat (Table 4). Weight gains were similar because, of course, the energy content of lean body tissue is much less than that of fat (Agricultural Research Council, 1965).

In general terms, obesity may result from an excessive appetite, an abnormally high capacity to digest food encrgy, an abnormal partition of retained energy between the principle tissue stores, protein and fat, or an abnormally low rate of heat loss. The present experiments showed that there were no differences in digestibility of energy between fat and lean rats on the same ration. All the other factors were important 
contributors to the development of obesity in the Zucker rat and all were probably interdependent.

Our results confirmed those of Zucker (1967) and Bray et al. (1973) that when food intake is restricted, 'fatty' rats show stunted growth of muscle and excessive deposition of fat at the same time. They also indicate that the cfficiency of retention of energy was inversely related to the rate of protein accretion, i.e. directly related to the proportion of metabolizable energy that was being used to synthesize fat. The 'fatties' therefore not only accumulated fat in abnormal proportions, but in excessive amounts, because their syntheses operated at a much greater energetic efficiency than the syntheses involved in normal growth. This point has not been established before. Bray \& York (197I) have reviewed the scanty and conflicting literature relating to metabolic rates of obese rodents. In many instances, the conditions under which metabolic rates were measured were not clearly stated. The only previous measurements that can be compared reliably are those made on fasted animals. Basal metabolic rate ( $\mathrm{kJ} /$ animal) has been reported to be higher in obesity in the 'fatty' rat (Bray, 1969), in rats with hypothalamic lesions (Brobeck, 1960), the NZO mouse (Subrahmanyam, 1960) and mice with gold thio-glucose lesions (Marshall \& Mayer, 1954). In all cases except the NZO mouse, this was simply because at the time of measurement the obese animals were bigger than lean controls. When basal metabolic rate was expressed per unit of metabolic body size (in this instance $W^{0 \cdot 7}$, Bray \& York, I97I) it was nearly always lower in 'fatty' individuals.

Though measurements of fasting metabolism do provide a useful baseline for comparative studies in energy metabolism, they cannot, by definition, describe the energy exchanges of an animal cating and growing in a normal fashion. In our expcriments metabolic rate was lower in fat rats than in lean rats when energy intake was the same; when fat and lean rats consumed food to appetite, metabolic rates were about the same, although energy intake and retention were much higher in 'fatties'. In both circumstances the gross efficiency of energy retention was greater in the fat individuals. The similarity between the metabolic rates of fat and lean rats consuming food ad lib. prompts the speculation that appetite in fat and lean rats may be regulated in some way to sustain an optimal metabolic rate during growth, perhaps linked to an optimal rate of protein turnover.

It was not possible to obtain a precise measurement of the spontaneous activity of fat and lean rats. Some measurements were made using an Animex electromagnctic induction activity recorder (kindly loaned by LKB Instruments, Croydon, Surrey), but this approach did not provide a complete record of activity, since any movements made more than about $60 \mathrm{~mm}$ from the floor were not counted. Nevertheless it appeared that activity patterns in fat and lean rats between 50 and $70 \mathrm{~d}$ of age offered food ad lib. were similar (Pullar \& Webster, 1973). We also found from direct observation that the activity of the fat rats was not noticeably less than that of their lean siblings until they became very obese, when, not surprisingly, they became very sluggish.

While the pattern of energy deposition in the rat can be influenced by eating habits, meal-eaters tending to deposit more fat than nibblers (Fábry, 1967; Leveille, I972), 
it is most unlikely that much of the difference between the fat and lean rats in this experiment can be attributed to this cause. Both types of eating behaviour were observed in both types of rats and there is no suggestion that it influenced the energy balances listed in Tables I and 2. However, the possible effects of eating behaviour on energy exchanges of fat and lean rats are now being investigated.

In conclusion, it seems reasonable to suggest that both the relatively low heat loss and the relatively high appetite of 'fatty' rats may result from the abnormality of metabolism that leads to an abnormal balance during growth between fat and protein deposition. Regulation of appetite in the fat rats therefore appeared to be directed towards the maintenance of a normal rate of skeletal and muscle growth. The consequences of this attempt to preserve normality were grotesque.

We are grateful to Mr A. W. Boyne for his advice in the design and statistical evaluation of these experiments.

\section{REFERENCES}

Agricultural Research Council (1965). The Nutrient Requirements of Livestock No. 2, Ruminants. London: Agricultural Research Council.

Arnal, M., Fauconneau, G. \& Pech, R. (1972). Annls Biol. anim. Biochim. Biophys. 12, gr.

Blaxter, K. L. (1 962). The Energy Meiabolism of Ruminants. London: Hutchinson Scientific and Technical.

Blaxter, K. L., Clapperton, J. L. \& Wainman, F. W. (1966). F. agric. Sci., Camb. 67, 67.

Bray, G. A. (1969). Experientia 25, I 100.

Bray, G. A. \& York, D. A. (197I). Physiol. Rev. 51, 598.

Bray, G. A., York, D. A. \& Swerloff, R. S. (1973). Metabolism 22, 435.

Breirem, K. (1939). Biedermanns Zbl. Tievernähr. II, 487 .

Brobeck, J. R. (1960). Recent Prog. Horm. Res. 16, 439.

Duncan, D. L. (1966). In Recent Advances in Animal Nutrition p. 51 [J. T. Abrams, editor]. London: Churchill.

Fábry, P. (I967). Handbook of Physiology Section 6, Alimentary Canal Vol. I, Ch. 3 [C. F. Code, editor]. Washington, DC: American Physiological Society.

James, W. P. T. (I972). Proc. Nutr. Soc. 31, 225.

Kielanowksi, J. (1965). Publs Eur. Ass. Anim. Prod. No. In, p. I3.

Kielanowski, J. \& Kotarbinska, M. (1970). Publs Eur. Ass. Anim. Prod. No. I3, p. 145.

Leveille, G. A. (1972). Nutr. Rev. 3o, r5r.

Marshall, N. B. \& Mayer, J. (1954). Am. Y. Physiol. r78, 27 1.

McCracken, K. J. (r973). Proc. Nutr. Soc. 32, 66 A.

Milligan, L. P. (1971). Fedn Proc. Fedn Am. Socs exp. Biol. 30, 1454.

Mount, L. E. (1968). The Climatic Physiology of the Pig. London: Edward Arnold.

Nehring, K. (1969). Publs Eur. Ass. Anin. Prod. No. 12, p. 5.

Ørskov, E. R. \& McDonald, I. (1970). Publs Eur. Ass. Anim. Prod. No. 13, p. rzi.

Oslagc, H. J., Gädeken, D. \& Fliegel, H. (1970). Publs Eur. Ass. Anim. Prod. No. 13, p. 133.

Pullar, J. D. (1969). In International Encyclopedia of Food and Nutrition Vol. 17, Nutrition of Animals of Agricultural Importance Part r, p. 47 [ [D. Cuthbertson, editor]. Oxford: Pergamon Press.

Pullar J. D. \& Webster, A. J. F. (1973). Proc. Nutr. Soc. 32, 19 A.

Schiemann, R. (1970). Wiss. Z. Humboldt-Univ. Berl., Math.-naturwiss. Reihe 19, 35.

Subrahmanyam, K. ( 1960$)$. Biochem. F. 76, 548.

Thorbek, G. (1970). Publs Eur. Ass. Anim. Prod. No. 13, p. 129.

Verstegen, M. W. A. (1971). Meded. LandbHoogesch. Wageningen p. $7 \mathrm{I}$.

Waterlow, J. C. (I969). In Mammalian Protein Metabolism Vol. 3, p. $36 \mathrm{x}$ [H. N. Munro, editor]. London and New York: Academic Press.

Weiss, P. \& Kavanau, J. L. (1957). F. ger. Physiol. 4I, I.

York, D. A. \& Bray, G. A. (1972). Endocrinology, 90, 885.

York, D. A., Hershmann, J. M., Utiger, R. D. \& Bray, G. A. (1972). Endocrinology 9o, 67.

Zucker, L. M. (r 967$)$. \%. Nutr. 91, 247.

Zucker, L. M. \& Antoniades, H. N. (1970). Fedn Proc. Fedn Am. Socs exp. Biol. 29, 379.

Zucker, L. M. \& Zucker, T. F. (r 96 I). F. Hered. 52, 275. 